\title{
RECONCILING GRADUATE ATTRIBUTE ASSESSMENT WITH EXISTING OUTCOME-BASED ASSESSMENT
}

\author{
D. Kennedy, Ph.D., P.Eng., Electrical Engineering, \\ K. Abercrombie, MA, Graduate Attribute Coordinator, \\ M. Bollo, M.Eng., P.Eng, Civil Engineering, \\ J. Jenness, Ph.D., P.Eng., Mechanical Engineering \\ British Columbia Institute of Technology \\ Diane_Kennedy@bcit.ca
}

\begin{abstract}
Historically, accreditation of engineering programs has relied on the use of input-based assessment of a program by framing major categories and identifying accreditation unit totals for each category. Beginning in 2014, compliance with an outcomes-based assessment of program quality and implementation of a program improvement process is also required.
\end{abstract}

The introduction of graduate attributes assessment at BCIT prompted faculty members to question the relationship between existing learning outcomes and indicators of graduate attributes. Since both outcomes and indicators are written to describe competencies, faculty hypothesized that correlation exists between them.

Upon further investigation, faculty, staff, and administrators at BCIT came to understand that there is a relationship between learning outcomes and indicators of graduate attributes, but they are not synonymous. Indicators are required to build a normalizing bridge between outcomes and attributes. They provide a rational relationship between a curriculum's individual course learning outcomes and the twelve graduate attributes mandated by the Canadian Engineering Accreditation Board.. This is especially important for subjective expectations of learning where there is not an obvious one-to-one relationship between learning outcomes and attributes

Keywords: graduate attributes; learning outcomes; outcome based assessment.

\section{INTRODUCTION}

The British Columbia Institute of Technology (BCIT) offers industry-informed programs with a focus on experiential teaching and learning, and outcomes-based assessment. Each course delivered at BCIT is required to develop a comprehensive list of learning outcomes embedded within a course outline. Learning outcomes specify what learners' new behaviours will be after a learning experience, and state the knowledge, skills, and attitudes that the students will gain through a course.

The establishment of a faculty wide engineering graduate attributes assessment project prompted questions of overlap between learning outcomes and indicators of graduate attributes. Faculty members wondered whether aspects of the graduate attributes project represented a duplication of activity, and they challenged the value of a separate, stand-alone process.

The graduate attributes project leadership group at BCIT embarked on a journey to define the relationship between the two. Faculty buy-in and project success would improve with this reconciliation.

\section{QUESTIONS}

In 2012 faculty leaders in each engineering department followed the recommendation of the Engineering Graduate Attributes Development Project (EGAD) and commenced the writing of indicators of graduate attributes. Indicators of graduate attributes are written to describe what the student will be able to do, the level of complexity at which they will do it, and the conditions under which learning will be demonstrated [3]. Existing learning outcomes were removed from the conversation and left in their independent and functioning role. Faculty members were lead through a workshop on writing indicators and a draft list of indicators was compiled [7][7].

Early contributors to, and adopters of, the graduate attribute framework recognized many similarities between learning outcomes and indicators of graduate attributes.

Learning outcomes and indicators of graduate attributes describe competencies. Both communicate expectations of learner's, and graduates' skills upon program 
completion. Both provide an objective benchmark for assessment. Faculty hypothesized that the extent to which correlation exists between them meant they could, in fact, be synonymous. Therefore, why have both learning outcomes and indicators of graduate attributes?

\section{ASSOCIATING LEARNING OUTCOMES AND INDICATORS OF GRADUATE ATTRIBUTES}

BCIT Faculty is counselled to write learning outcomes that 'define coherent units of learning that can be further subdivided or modularized for classroom or for other delivery' [9]. For a typical course in an engineering program, the recommended number of learning outcomes is 5 to 12 . Table 1 summarizes the total number of learning outcomes defined for each program.

Table 1: Program Courses, Learning Outcomes and Indicators

\begin{tabular}{|l|c|c|c|}
\hline & $\begin{array}{l}\text { Number } \\
\text { of } \\
\text { Courses }\end{array}$ & $\begin{array}{l}\text { Number } \\
\text { of } \\
\text { Learning } \\
\text { Outcomes }\end{array}$ & $\begin{array}{l}\text { Number } \\
\text { of } \\
\text { Indicators }\end{array}$ \\
\hline $\begin{array}{l}\text { Civil } \\
\text { Engineering }\end{array}$ & 80 & 609 & 73 \\
\hline $\begin{array}{l}\text { Electrical } \\
\text { Engineering }\end{array}$ & 52 & 546 & 73 \\
\hline $\begin{array}{l}\text { Mechanical } \\
\text { Engineering }\end{array}$ & 59 & 533 & 73 \\
\hline
\end{tabular}

A specific example, Electrical Engineering's ELEX 7720 - Linear Feedback Control, has 11 defined course learning outcomes, shown in Table 2.

Table 2: ELEX 7720 Linear Feedback Control Course Learning Outcomes

\begin{tabular}{|l|l|}
\hline 1 & Define what is linear feedback control. \\
\hline 2 & $\begin{array}{l}\text { Describe the conditions for and limitations of } \\
\text { linear feedback control. }\end{array}$ \\
\hline 3 & $\begin{array}{l}\text { Prepare a set of control system performance } \\
\text { objectives. }\end{array}$ \\
\hline 4 & $\begin{array}{l}\text { Propose measures by which performance may be } \\
\text { gauged. }\end{array}$ \\
\hline 5 & $\begin{array}{l}\text { Recommend an appropriate control strategy to use } \\
\text { based on process characteristics and performance } \\
\text { objectives. }\end{array}$ \\
\hline 6 & $\begin{array}{l}\text { Design a 3-term PID controller using an } \\
\text { appropriate choice of empirical, semi-empirical, } \\
\text { or analytic approach. }\end{array}$ \\
\hline 7 & $\begin{array}{l}\text { Describe practical concepts and limitations of } \\
\text { controller implementation such as direct/reverse } \\
\text { acting controllers, bump-less transfer, and } \\
\text { integrator anti-windup schemes. }\end{array}$ \\
\hline 8 & $\begin{array}{l}\text { Justify reducing the order of a system model and } \\
\text { approximating nonlinear terms, in order to make }\end{array}$ \\
\hline
\end{tabular}

\begin{tabular}{|c|l|}
\hline & $\begin{array}{l}\text { the problem tractable for linear process control } \\
\text { design }\end{array}$ \\
\hline 9 & $\begin{array}{l}\text { Analyze implications of making model } \\
\text { simplifications on the final system performance. }\end{array}$ \\
\hline 10 & $\begin{array}{l}\text { Design controllers using both time domain and } \\
\text { frequency domain approaches. }\end{array}$ \\
\hline 11 & $\begin{array}{l}\text { Develop facility with tools including Labview, } \\
\text { MATLAB, and Simulink for use in process } \\
\text { modeling, controller design, and simulation and } \\
\text { analysis. }\end{array}$ \\
\hline
\end{tabular}

Notice the tight coupling of language used in the expression of the learning outcomes to course content and the technical knowledge that will be gained as a result of taking the course. Also notice that the list of learning outcomes tends to shadow module delivery.

When asked to reflect upon which graduate attributes were being developed in this course, the instructor reported attributes 1-7 of the twelve listed in Table 3 .

Table 3: Engineering Graduate Attributes

\begin{tabular}{|ll|}
\hline 1. & Knowledge base for engineering \\
\hline 2. & Problem analysis \\
\hline 3. & Investigation \\
\hline 4. & Use of engineering tools \\
\hline 5. & Design \\
\hline 6. & Individual and team work \\
\hline 7. & Communication skills \\
\hline 8. & Professionalism \\
\hline 9. & Impact on society and environment \\
\hline 10. & Ethics and equity \\
\hline 11. & Economics and project management \\
\hline 12. & Lifelong learning \\
\hline
\end{tabular}

The development of these attributes, in particular attributes 6 and 7, are not at first glance easily recognizable from the listed learning outcomes.

If it is agreed that each learning outcome should exhibit a direct line of sight to one or more graduate attributes, and if the team purports that assessing a learning outcome with an existing assessment tool will help gather direct evidence of mastery of a graduate attribute, then the outline of a relationship has been established.

The graduate attributes leadership team embarked on an exercise to associate learning outcomes and attributes. In some cases, there was an obvious 1:1 relationship, however, in other cases the relationship was 1:many. The graduate attributes leadership team also recognized another truth associated with the identity of these core components. Learning outcomes were used to measure an individual's performance in a course, whereas indicators 
of attributes were used to measure a program's performance and overall effectiveness.

With this information in mind, faculty members began to map learning outcomes to indicators, and to graduate attributes. The initial hypothesis was: if it is possible to show a one-to-one relationship between a learning outcome and an indicator, then it is possible to use the existing assessment tool (or part of it) for that outcome as a direct measure of a graduate attribute.

\section{FINDINGS}

In practice, indicators provide a bridge between the course-focused learning outcomes and the programfocused attributes. Indicators also provide a leap pad between approximately 1700 learning outcomes and the 12 attributes, making it possible to show direct linkages between outcomes and attributes for the purpose of data collection.

Referring back to the ELEX 7720 example, it is perhaps not surprising that some of the more technically focused graduate attributes, for example '2: Problem Analysis', could clearly be related one-to-one between an indicator of the graduate attribute and a stated course learning outcome, as shown in Table 4.

Table 4: One-to-one mapping of ELEX 7720 learning outcomes and indicators of problem analysis

\begin{tabular}{|l|l|}
\hline Learning Outcome & $\begin{array}{l}\text { Indicators of Problem } \\
\text { Analysis }\end{array}$ \\
\hline $\begin{array}{l}\text { 5. Recommend an } \\
\text { appropriate control strategy } \\
\text { to use based on process } \\
\text { characteristics and } \\
\text { performance objectives. }\end{array}$ & $\begin{array}{l}\text { 2.2.3 Select the best } \\
\text { process to solve an } \\
\text { engineering problem. }\end{array}$ \\
\hline $\begin{array}{l}\text { 8. Justify reducing the } \\
\text { order of a system model } \\
\text { and approximating } \\
\text { nonlinear terms, in order to } \\
\text { make the problem tractable } \\
\text { for linear process control } \\
\text { design }\end{array}$ & $\begin{array}{l}\text { 2.2.1 Create a } \\
\text { process/solution method for } \\
\text { solving a problem, } \\
\text { including forming justified } \\
\text { approximations and } \\
\text { assumptions }\end{array}$ \\
\hline
\end{tabular}

Furthermore, for example in the case of the graduate attribute '5: Use of Engineering Tools', if the learning outcome was broken down into sub-outcomes, a mapping to indicators of this graduate attribute could be made, as shown in Table 5.

Table 5: One-to-one mapping of ELEX 7720 learning suboutcomes and indicators of use of engineering tools

\section{Learning Outcome}

11. Develop facility with tools including Labview, MATLAB, and Simulink for use in process modeling,

\begin{tabular}{|l|l|}
\hline controller design, and simulation and analysis. \\
\hline Learning Sub-Outcome & $\begin{array}{l}\text { Indicators of Use of } \\
\text { Engineering Tools }\end{array}$ \\
\hline $\begin{array}{l}\text { 11.1 The student can } \\
\text { combine tools including } \\
\text { Labview, MATLAB, } \\
\text { and Simulink to take } \\
\text { maximum advantage of } \\
\text { their use in process } \\
\text { modeling, controller } \\
\text { design and } \\
\text { implementation, and } \\
\text { simulation and analysis. }\end{array}$ & $\begin{array}{l}\text { modeling and strims of tools for (i) } \\
\text { Monitoring system } \\
\text { performance, and (iv) creating } \\
\text { engineering designs. }\end{array}$ \\
\hline $\begin{array}{l}\text { 11.2 The student can use } \\
\text { Simulink to construct a } \\
\text { simulation of a non- } \\
\text { linear dynamical system }\end{array}$ & $\begin{array}{l}\text { 5.2.2 Demonstrate } \\
\text { proficiency in using discipline } \\
\text { specific tools }\end{array}$ \\
\hline $\begin{array}{l}11.3 \text { The student can } \\
\text { select the appropriate } \\
\text { numerical integration } \\
\text { technique to minimize } \\
\text { Simulink numerical } \\
\text { errors }\end{array}$ & $\begin{array}{l}\text { 5.3.2 Verify the credibility of } \\
\text { results from tool use; } \\
\text { appreciate the accuracy and } \\
\text { limitations, and the } \\
\text { assumptions inherent in their } \\
\text { use. }\end{array}$ \\
\hline
\end{tabular}

It turns out that for ELEX 7720, graduate attributes 1 to 5 can be connected one-to-one with the learning (sub)outcomes defined for this course.

Graduate attributes ' 6 : Individual and Team work' and ' 7 : Communication' do not fit into this framework. The instructor did not have a stated learning objective that could be mapped to an indicator of the graduate attribute. Rather, development of attainment of these attributes is embedded in expectations of formal laboratory reports and oral presentations, and requirement for participation in team project work. In other words, the learning associated with these attributes is woven into the course. Development of these attributes often occurs as a result of how the course is delivered: the method, the mode, the model.

We have come to understand that there is a relationship between learning outcomes and indicators of graduate attributes, but they are not synonymous. The graduate attributes provide a comprehensive statement of competency, and are both explicit and implicit expectations in course work. Course learning outcomes are highly specific to course content and always explicit, measurable statements of expectation and competency.

\section{GRADUATE ATTRIBUTE INFORMATION FROM LEARNING OUTCOME ASSESSMENT}


Where there is a one-to-one relationship between learning outcome (or sub-outcome) and indicator, it is possible to use existing assessments to gather direct evidence of competency. However, if there is no one-to-one relationship between learning outcome and indicator, as is the case for most of the subjective attributes, an assessment tool must be developed to ensure an "applesto-apples" comparison. A rubric tool where each line of the rubric represents an indicator is a perfect assessment tool for this purpose.

The following is a case study from Civil Engineering CIVL 7090 - Capstone Design Project, demonstrating the use of indicators as a bridge between learning outcomes and graduate attributes. The result is an assessment tool developed for a particular outcome that can be used to collect direct evidence of graduate attribute mastery.

In order to progress in our understanding of the relationship between learning outcomes and indicators of graduate attributes, Civil Engineering faculty members were asked to complete a matrix for each of their courses. In the left column is a list of learning outcomes. The twelve columns on the right represent the twelve graduate attributes. Faculty members were asked to indicate if each learning outcome related to each of the twelve attributes. As shown in Table 6, CIVL 7090, maps its learning outcomes as shown, resulting in formation of a one-tomany relationship between learning outcomes and graduate attributes.

Table 6: CIVL 7090 - Capstone Design Learning Outcome to Graduate Attribute Mapping

\begin{tabular}{|c|c|c|c|c|c|c|c|c|c|c|c|c|}
\hline \multirow{2}{*}{$\begin{array}{l}\text { CIVL } 7090 \text { Course } \\
\text { Learning Outcomes }\end{array}$} & \multicolumn{12}{|c|}{ CEAB Graduate Attributes } \\
\hline & 1 & 2 & 3 & 4 & 5 & 6 & 7 & 8 & 9 & $\begin{array}{l}\mathbf{1} \\
\mathbf{0}\end{array}$ & $\begin{array}{l}1 \\
1\end{array}$ & $\begin{array}{l}1 \\
2\end{array}$ \\
\hline $\begin{array}{l}\text { Design a civil } \\
\text { engineering project } \\
\text { from conception } \\
\text { through to a completed } \\
\text { plan. }\end{array}$ & $\mathbf{X}$ & $\mathbf{X}$ & $\mathbf{X}$ & $\mathbf{X}$ & $\mathbf{X}$ & $\mathbf{X}$ & $\mathbf{X}$ & $\mathbf{X}$ & $\mathbf{X}$ & $\mathbf{X}$ & $\mathbf{X}$ & $\mathbf{X}$ \\
\hline $\begin{array}{l}\text { Integrate information, } \\
\text { ideas and concepts } \\
\text { from previous courses } \\
\text { into a comprehensive } \\
\text { design effort. }\end{array}$ & $\mathbf{X}$ & $\mathbf{X}$ & $\mathbf{X}$ & $\mathbf{X}$ & $\mathbf{X}$ & $\mathbf{X}$ & $\mathbf{X}$ & & $\mathbf{X}$ & & $\mathbf{X}$ & $\mathbf{X}$ \\
\hline $\begin{array}{l}\text { Apply civil } \\
\text { engineering concepts } \\
\text { to real-world } \\
\text { engineering practice. }\end{array}$ & $\mathbf{X}$ & $\mathbf{X}$ & $\mathbf{X}$ & $\mathbf{X}$ & & & $\mathbf{X}$ & $\mathbf{X}$ & $\mathbf{X}$ & $\mathbf{X}$ & $\mathbf{X}$ & $\mathbf{X}$ \\
\hline $\begin{array}{l}\text { Critically assess } \\
\text { engineering decisions }\end{array}$ & $\mathbf{X}$ & $\mathbf{X}$ & $\mathbf{X}$ & $\mathbf{X}$ & & & & $\mathbf{X}$ & $\mathbf{X}$ & $\mathbf{X}$ & $\mathbf{X}$ & $\mathbf{X}$ \\
\hline
\end{tabular}

with respect to economic implications and environmental and societal impact.

Work collaboratively as part of a team to complete a project according to predetermined specifications.

Produce a list of references that demonstrate library $\begin{array}{llllllll}\text { and internet searches to } & \mathbf{X} & \mathbf{X} & \mathbf{X} & \mathbf{X} & \mathbf{X}\end{array}$

find specific engineering information.

Write an engineering report to industry standards.

Make formal oral presentations summarizing individual design work.

In order to manage this one-to-many relationship, the faculty member developed an assessment tool for a single learning outcome with the capability of measuring mastery for several attributes. For example, CIVL 7090 has eight defined learning outcomes, one of which is "Write an engineering report to industry standards". This learning outcome has association with nine graduate attributes. In the rubric associated with the marking of the final report for the Capstone project, data for seven of the nine graduate attributes are assessed using nineteen indicators of graduate attributes, a portion of which is shown in Table 7. A separate sheet contained descriptors of the five levels of mastery for each project component.

Table 7: CIVL 7090 Capstone Design Project Report Marking Rubric

\begin{tabular}{|c|c|c|c|c|c|c|c|}
\hline & & \multicolumn{5}{|c|}{ Level of Mastery } & \multirow[b]{2}{*}{$\begin{array}{c}\text { Grad Attrib } \\
\text { Indicator } \\
\text { Ref.\# }\end{array}$} \\
\hline & & $\begin{array}{l}\text { Below } \\
\text { Expect } \\
\text { ations }\end{array}$ & $\begin{array}{l}\text { Devel } \\
\text { oping }\end{array}$ & $\begin{array}{c}\text { Compe } \\
\text { tent }\end{array}$ & $\begin{array}{l}\text { Profi } \\
\text { cient }\end{array}$ & $\begin{array}{l}\text { Exceeds } \\
\text { Expectati } \\
\text { ons }\end{array}$ & \\
\hline COMPONENT & LEVEL: & 1 & 2 & 3 & 4 & 5 & \\
\hline \multicolumn{2}{|c|}{$\begin{array}{l}\text { Report Appearance: } \\
\text { General appearance, } \\
\text { Title page, Table of } \\
\text { Contents, disclaimer }\end{array}$} & & & & & & \\
\hline \multicolumn{2}{|c|}{ Executive Summary } & & & & & & 7.1 .2 \\
\hline \multicolumn{2}{|c|}{$\begin{array}{l}\text { Writing Skill: } \\
\text { organization, } \\
\text { spelling, grammar, }\end{array}$} & & & & & & 7.1.2 \\
\hline
\end{tabular}




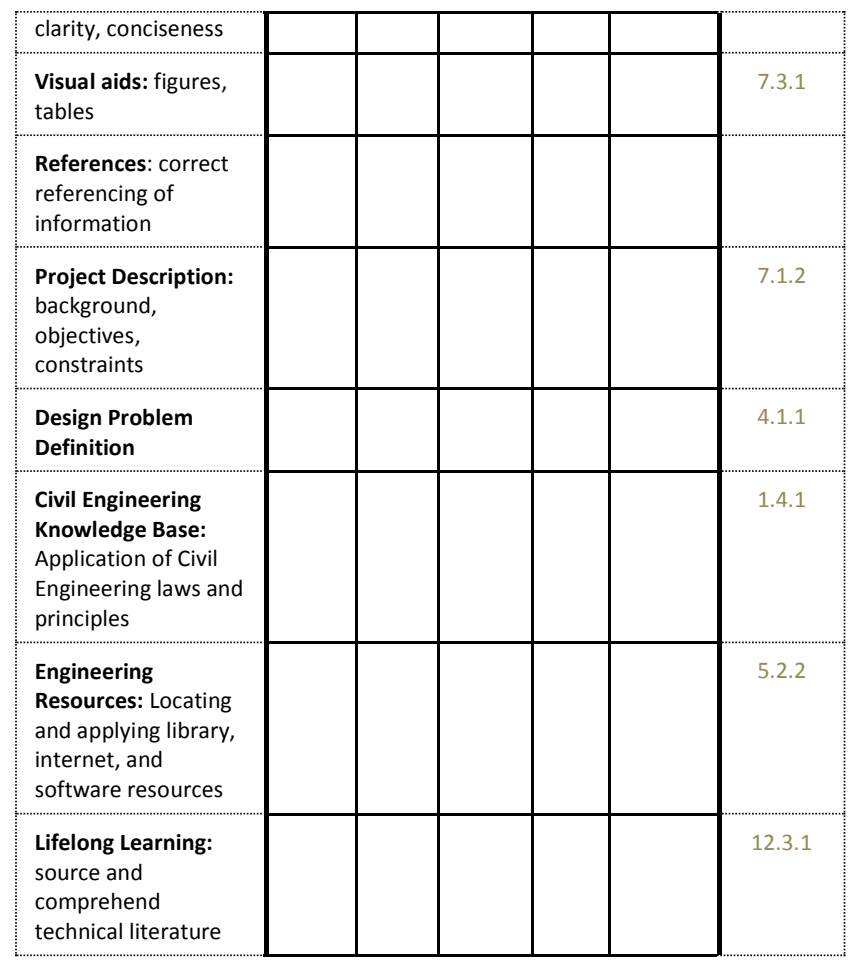

The relationship between learning outcomes, indicators, and graduate attributes is complex. Indicators are required to build a normalizing bridge between outcomes and attributes. In other words, indicators provide a rational relationship between the program learning outcomes and the graduate attributes, especially for subjective expectations of learning where there is not an obvious one-to-one relationship between an outcome and an attribute.

\section{MOVING FORWARD}

The twelve graduate attributes provide an excellent framework to ensure program quality. A clear understanding of the equilibrium-like relationship between learning outcomes and graduate attributes allows faculty members to (a) ensure a direct line of sight between course-based learning outcomes and attributes, and (b) an opportunity to reflect on gaps in the list of indicators.

The graduate attribute project provides an opportunity to revisit learning outcomes to ensure they align with the industry-valued graduate attributes. Over time, direct evidence of learning, modification of assessment tools, and edited lists of indicators will help ensure all stakeholders keep program quality front of mind.
Initially, the graduate attributes project leadership group anticipates an overlap of learning outcomes and indicators of graduate attributes, shown in Figure 1, that allows for some outlying outcomes. We will be challenged to consider whether these learning outcomes are relevant. For example, application of the rubric for CIVIL 7090 led to the realization that there was no indicator (providing linkage to graduate attributes) for one line in the rubric that the instructor deemed important to assess. If the learning outcome is deemed relevant, we will be motivated to modify our indicators to ensure we include what's important.

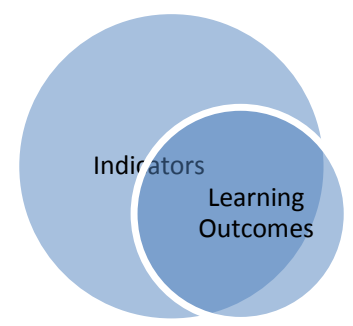

Fig. 1: Current Learning Outcome to Graduate Attribute Mapping

As the graduate attributes project progresses, we anticipate an alignment between learning outcomes and graduate attributes represented by a set of circles where the learning outcome set is completely enclosed by the graduate attributes but not perfectly superimposed, as shown in Figure 2. The gap where there are no learning outcomes, but still graduate attribute development and assessment required, will prompt the need for assessment tools, such as the rubric for CIVIL 7090.

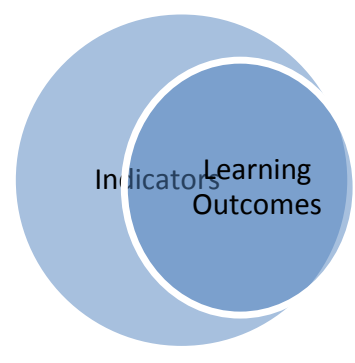

Fig. 2: Learning Outcome to Graduate Attribute Mapping

Over time, as the data analysis guides program review, we expect that explicit learning outcomes will be written to cover previous gaps, eventually resulting in a two perfectly superimposed circles, Figure 3. 


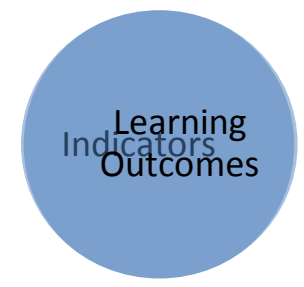

Education Association, (Winnipeg, MB: June 17 - 20) 3 pp., 2012.

[9] "Writing learning outcomes" job aid. Available as of April 14,2014 , from http://www.bcit.ca/ltc/instructors/teachtest.shtml.

Fig. 3: Learning Outcome to Graduate Attribute Mapping

En route to two perfectly aligned circles, the process will be iterative and organic. This prompts a review of the relevant indicators and the cyclical process of program improvement continues.

\section{References}

[1] ACCME Commons Web-Link to Indicators. Available as of April 14, 2014, from

http://commons.bcit.ca/graduateattributes/files/2014/03/Att ribute-Indicator-MASTER-V4-30Jan2014.pdf

[2] “Tracking of program issues", CEAB Visiting Team Working Document. Available as of April 14, 2014 from http://www.engineerscanada.ca/sites/default/files/w_trackin g_program_issues_english.doc.

[3] EGAD Resources on Graduate Attribute Assessment. Available as of April 14, 2014, from http://egad.engineering.queensu.ca/

[4] J. Kaupp, et. al., "A Comparison of Institutional Approaches to CEAB Graduate Attribute Requirements," in Proceedings of the Canadian Engineering Education Association, (Winnipeg, MB: June 17 - 20) 7 pp., 2012.

[5] J. Kaupp, et. al., "Evaluation of software tools supporting outcomes-based continuous program improvement processes," in Proceedings of the Canadian Engineering Education Association, (Montreal, QC: June 17 - 20) 8 pp., 2013.

[6] Klein-Collins, R. (2013, October), Sharpening Our Focus on Learning: The Rise of Competency-Based Approaches to Degree Completion (Occasional Paper No. 20). Urbana, IL: University of Illinois and Indiana University, National Institute for Learning Outcomes Assessment.

[7] P. Ostafichuk, "Graduate Attribute Assessment as a Course Instructor", BCIT Graduate Attributes Workshop.

Available as of April 14, 2014, from http://commons.bcit.ca/graduateattributes/

[8] D. Spracklin-Reid and A. Fisher, "Course-Based Learning Outcomes as the Foundation for Assessment of Graduate Attributes," in Proceedings of the Canadian Engineering 